\title{
MEMAHAMI DAN MENDESKRIPSIKAN HUBUNGAN NEGARA HUKUM DENGAN HAM
}

\author{
Dany Try Hutama Hutabarat ${ }^{1}$, Ade Wahyuni ${ }^{2}$, Dela Amalia Vada ${ }^{3}$, Eko Anuary Sitorus ${ }^{4}$, \\ Rizka Efrianti Nasution ${ }^{5}$, Yuni Widia Astuti ${ }^{6}$ \\ $1-6$ \\ Program Studi Ekonomi Pembangunan, Fakultas Ekonomi, Universitas Asahan \\ E-mail: ${ }^{1)}$ Danytryhutamahutabat@gmail.com, ${ }^{2)}$ adewahyuni01052001@gmail.com, \\ 3) dellavada025@gmail.com, ${ }^{4)}$ anvaryeko@gmail.com, \\ ${ }^{5)}$ tinanasution351@gmail.com, 6) widyaastutiyuni@gmail.com
}

\begin{abstract}
Human rights on the one hand by the concept of natural law is an inherent right of every individual human being since birth, but on the other hand the legality of human rights must be shaped by the flow of positivism. The debate over whether human rights should be stipulated in the constitution also influence the discussion of the UUD 1945. Finally, the UUD 1945 amendments regulate the basic rights of citizens more fully starts from the premise that human rights protection is an important element in the concept of a constitutional state. Incorporated therein also setting mechanism of "judicial review" in the Constitutional Court as a means to avoid any legislation contrary to the fundamental rights of citizens as guaranteed in the constitution.
\end{abstract}

Keywords: Human Rights, State of Law, Constitutional Court

\begin{abstract}
Abstrak
Hak asasi manusia pada satu sisi menurut konsep hukum alam adalah suatu hak yang melekat pada setiap individu manusia sejak dilahirkan, tetapi pada sisi lain hak asasi harus berbentuk legalitas menurut aliran positivisme. Perdebatan apakah hak asasi manusia harus diatur dalam konstitusi juga mewarnai pembahasan UUD 1945. Akhirnya amandemen UUD 1945 mengatur hak-hak dasar warganegara secara lebih lengkap bertitik tolak dari pemikiran bahwa perlindungan hak asasi manusia merupakan satu elemen penting dalam konsep negara hukum. Dimasukkan di dalamnya juga pengaturan mekanisme "judicial review" di Mahkamah Konstitusi sebagai sarana untuk menghindari adanya peraturan yang bertentangan dengan hak-hak dasar warga negara sebagaimana dijamin dalam konstitusi
\end{abstract}

Kata Kunci: HAM, Negara Hukum, Mahkamah Konstitusi

\section{PENDAHULUAN}

Negara Indonesia adalah negara hukum oleh sebab itu segala sesuatu tindakan penyelenggara negara harus berdasarkan hukum. Indonesia merupakan negara hukum modern di tuntut adanya peranan dan fungsi hukum secara stabil dan dinamis yang mampu mengatur berbagai kepentingan tanpa meninggalkan ide dasarnya yaitu keadilan. Secara teori negara hukum (rechtstaat) adalah negara yang bertujuan untuk menyelenggarakan ketertiban umum yakni tata tertib yang berdasarkan hukum yang terdapat pada rakyat.

Konsep negara hukum menduduki ide perlindungan hak asasi manusia sebagai salah satu peran penting. Dengan mempertimbangkan urgensinya perlindungan hak asasi manusia 
tersebut, maka konstitusi harus memuat pengaturan hak asasi manusia agar ada jaminan negara terhadap hak-hak warga negara. Salah satu perubahan penting dalam Amandemen UUD 1945 adalah pengaturan hak warga negara lebih komprehensif dibanding UUD 1945 (pra-amandemen) yang mengatur secara umum dan singkat. Catatan pelanggaran hak asasi manusia yang buruk di era Pemerintahan Orde Baru di bawah Presiden Suharto memberi pelajaran bahwa setidaknya pengaturan hak-hak warga negara harus lebih rinci di dalam konstitusi. Amandemen UUD 1945 juga membuat pranata peradilan melalui Mahkamah Konstitusi untuk menggugat produk perundangundangan yang melanggar hak-hak warga negara sebagaimana diatur dalam konstitusi.

Oleh karena itu, dalam paham negara hukum, jaminan perlindungan HAM dianggap sebagai ciri yang mutlak harus ada di setiap negara yang dapat disebut rechsstaat (Assiddiqie, 2012). Dalam konteks negara hukum, melalui Undang- Undang Dasar Republik Indonesia 1945, politik hukum nasional telah menetapkan bahwa Indonesia adalah negara hukum, sebagaimana diatur dalam Pasal 1 ayat (1) Undang-Undang Dasar Republik Indonesia Tahun 1945 (Marbun, 2014). Sebagai konsekuensi Indonesia adalah negara hukum sebagai mana termaktub didalam UndangUndang Dasar Republik Indonesia Tahun 1945 tersebut, maka usaha untuk mempertahankan dan melindungi HAM itu adalah menjadikan HAM tersebut sebagai bagian dari hukum nasional (Yuliartha, 2009).

Hak asasi manusia merupakan nilai-nilai universal yang telah diakui secara universal. Berbagai instrumen internasional mewajibkan negara-negara peserta untuk memberikan jaminan perlindungan dan pemenuhan hak warga negara. Indonesia merupakan hukum yang memiliki sejarah panjang dalam perjuangan perlindungan hak asasi manusia. Sebagai negara hukum yang demokratis, Indonesia telah meratifikasi berbagai instrumen hukum internasional. Perubahan mendasar dalam politik penegakan hak asasi manusia setelah reformasi 1998 tetapi tidak dapat dilepaskan dari sejarah panjang perjuangan sebelumnya.

Gerakan reformasi politik yang bergulir pada tahun 1998 memunculkan ide pentingnya pengaturan hak warga negara dalam UUD, karena kuatnya desakan keinginan rakyat untuk menikmati kehidupan ketatanegaraan yang demokratis berdasarkan hukum. Keinginan rakyat tersebut tidak dapat dilepaskan dari pengalaman ketatanegaraan di bawah Presiden Soekarno dan Presiden Soeharto. Pasca gerakan reformasi 1998, muncul gerakan dilakukannya amandemen UUD 1945. Amandemen UUD 1945 tidak boleh memberikan peluang bagi munculnya praktik penyelenggaraan negara dengan kekuasaan eksekutif sebagai pendulum utama (executive heavy) seperti terjadi di masa lalu. Demikian pula harus dicegah praktik ketatanegaraan dengan pendulum mengarah pada legislatif (legislative heavy).

Amandemen UUD 1945 telah memasukkan jaminan perlindungan dan pemenuhan hak warga negara dalam konstitusi. Beberapa Pasal di dalam UUD NRI Tahun 1945 mengatur secara komprehensif tentang hak-hak asasi warga negara dan sekaligus kewajiban negara. Pengaturan dan implementasi hak-hak asasi warga negara dan kewajiban negara selayaknya dua sisi mata uang. Beberapa Pasal yang dapat disebutkan adalah sebagai berikut: Pasal 26 (penduduk dan warga negara), Pasal 27 (jaminan persamaan di muka hukum dan pemerintahan), Pasal 29 (kebebasan beragama), Pasal 30 (pertahanan negara), Pasal 31 (pendidikan), dan Pasal 32 (kebudayaan daerah). 


\section{JOURNAL OF HUMANITIES, SOCIAL SCIENCES AND BUSINESS \\ (JHSSB) \\ VOLUME 1 ISSUE 2 (2022)}

Perubahan mendasar dalam amandemen UUD 1945 adalah pengaturan yang cukup komprehensif tentang jaminan hak warga negara yang diatur pada Pasal 28, Pasal 28A-Pasal 28J (pengaturan rinci jaminan hak-hak warga negara).

a) Pasal 28A: hak untuk hidup dan hak mempertahankan hidup dan kehidupannya.

b) Pasal 28B:

1) hak membentuk keluarga melalui perkawinan yang sah,

2) hak melanjutkan keturunan melalui perkawinan yang sah,

3) hak anak atas kelangsungan hidup, tumbuh, dan berkembang, dan

4) 4) hak anak atas perlindungan dari kekerasan dan diskriminasi.

c) Pasal 28C:

1) hak mengembangkan diri melalui pemenuhan kebutuhan dasarnya,

2) hak mendapat pendidikan demi meningkatkan kualitas hidupnya dan demi kesejahteraan umat manusia,

3) hak memperoleh manfaat dari ilmu pengetahuan dan teknologi, seni dan budaya, demi meningkatkan kualitas hidupnya dan demi kesejahteraan. umat manusia,

4) hak untuk memajukan dirinya dalam memperjuangkan haknya secara kolektif untuk membangun masyarakat, bangsa dan negaranya.

d) Pasal 28D:

1) hak atas pengakuan, jaminan, perlindungan, dan kepastian hukum yang adil serta perlakuan yang sama dihadapan hukum,

2) hak untuk bekerja serta mendapat imbalan dan perlakuan yang adil dan layak dalam hubungan kerja,

3) hak memperoleh kesempatan yang sama dalam pemerintahan, 4) hak atas status kewarganegaraan.

e) Pasal 28E:

1) hak bebas memeluk agama dan beribadat menurut agamanya,

2) hak memilih pendidikan dan pengajaran,

3) hak memilih pekerjaan,

4) hak memilih kewarganegaraan,

5) hak memilih tempat tinggal di wilayah negara dan meninggalkannya, serta berhak kembali,

6) hak untuk bebas meyakini kepercayaan, menyatakan pikiran dan sikap, sesuai dengan hati nuraninya,

7) hak atas kebebasan berserikat,

8) hak atas kebebasan berkumpul,

9) hak atas kebebasan mengeluarkan pendapat.

f) Pasal 28F:

1) Hak untuk berkomunikasi dan memperoleh informasi guna mengembangkan pribadi dan lingkungan sosialnya dan,

2) berhak untuk mencari, memperoleh, memiliki, menyimpan, mengolah dan menyampaikan informasi dengan menggunakan segala jenis saluran yang tersedia.

g) Pasal 28G:

1) hak atas perlindungan diri pribadi, keluarga, kehormatan, martabat, dan harta 
benda yang di bawah kekuasaannya,

2) hak atas rasa aman dan perlindungan dari ancaman ketakutan untuk berbuat atau tidak berbuat sesuatu yang merupakan hak asasi,

3) hak untuk bebas dari penyiksaan dan perlakuan yang merendahkan derajat martabat manusia,

4) hak memperoleh suaka politik dari negara lain.

h) Pasal 28H:

1) hak hidup sejahtera lahir dan batin,

2) hak bertempat tinggal,

3) hak mendapatkan lingkungan hidup baik dan sehat,

4) hak memperoleh pelayanan kesehatan,

5) mendapat kemudahan dan perlakuan khusus untuk memperoleh kesempatan dan manfaat yang sama guna mencapai persamaan dan keadilan,

i) Pasal 28I ayat (1):

1) hak asasi manusia yang tidak dapat dikurangi dalam keadaan apapun,

2) hak untuk hidup,

3) hak untuk tidak disiksa,

4) hak kemerdekaan pikiran dan hati nurani,

5) hak beragama,

6) hak untuk tidak diperbudak,

7) hak untuk diakui sebagai pribadi dihadapan hukum,

8) hak untuk tidak dituntut atas dasar hukum yang berlaku surut.

j) Pasal 28I ayat (2):

1) hak bebas atas perlakuan yang bersifat diskriminatif atas dasar apa pun,

2) hak mendapatkan perlindungan terhadap perlakuan yang bersifat diskriminatif.

Jaminan perlindungan dan pemenuhan hak warga negara tersebut perlu didukung oleh kebijakan pemerintah dalam mengimplementasikan norma-norma dasar dalam UUD 1945. Selain kewajiban dan tugas pemerintah, sebagai negara hukum yang demokratis, warga negara Indonesia harus diberikan ruang yang luas untuk berpartisipasi guna mempertahankan dan pemenuhan hak-hanya. Salah satu mekanisme yang dibangun dalam UUD 1945 adalah dengan melakukan pengujian terhadap peraturan perundang-undangan dan keputusan/tindakan adminsitrasi yang dianggap melanggar hak warga negara dan bertentangan dengan UUD 1945. Mekanisme melalui pengujian oleh kekuasaan kehakiman dikenal dengan judicial review.

\section{METODE PENELITIAN}

Dalam penelitian ini menggunakan metode pendekatan yuridis normatif / doktrinal, sehingga data yang diperlukan meliputi data sekunder yang dilakukan dengan studi pustaka atau "literature study". Sedangkan metode analisa data yang dipergunakan bersifat Analisis Kualitatif Normatif 


\section{JOURNAL OF HUMANITIES, SOCIAL SCIENCES AND BUSINESS (JHSSB) \\ VOLUME 1 ISSUE 2 (2022)}

\section{TEMUAN DAN PEMBAHASAN}

Negara hukum adalah negara yang didalamnya terdapat aspekaspek peraturan-peraturan yang memang bersifat abstrak yaitu bersifat memaksa,dan mempunyai sanksi yang tegas.

Van Volen Hoven pernah mengemukakan bahwa negara layaknya "Burung", yang akan terbang bebas. Dalam suatu negara jika tidak ada hukum yang membatasinya, maka bisa saja negara itu jua akan terbang bebas, semaunya. Diperlukan hukum administrasi negara untuk membatasi kebebasan negara itu dalam bertindak. Keberadaan hukum administrasi negara dianggap dapat membatasi kewenangan dari lembaga yang menjalankan ketatanegaraan ini, agar tak sewenang-wenang dalam bertindak di lapangan pemerintahan. Kuntjoro Purbopranoto sebagaimana dikutip oleh Hadjon mengetengahkan beberapa definisi dan deskripsi hukum administrasi dengan mengemukakan bahwa obyek hukum administrasi adalah peraturan-peraturan yang mengatur hubungan timbal balik antara pemerintah dan rakyat (Al-Khawarizmi, 2011). Dalam konsep hukum, hukum adminstrasi negara termasuk dalam wilayah hukum public (hukum negara), yaitu hukum yang mengatur hubungan antara warga negara dengan alat-alat perlengkapan atau hubungan antara negara dan perseorangan (warga negara). hukum administrasi negara di ciptakan agar memungkinkan administrasi negara menjalankan fungsinya, dan melindungi administrasi negara dari melakuan perbuatan yang salah menurut hukum.

\subsection{Konsepsi Negara Hukum Pancasila dalam Kaitannya dengan HAM}

Konsep negara hukum yang dianut dalam Undang-Undang Dasar Republik Indonesia Tahun 1945 adalah negara hukum yang aktif dan dinamis. Model negara hukum seperti ini menjadikan sebagai pihak yang aktif berorientasi pada pemenuhan dan perwujudan kesejahteraan rakyat sesuai dengan prinsip welvaarstaat (Ridlwan, 2011).

Sebagai negara hukum, segala tindakan penyelenggara negara dan warga negara harus sesuai dengan aturan hukum yang berlaku. Hukum dalam hal ini adalah hierarki tatanan norma yang berpuncak pada konstitusi, yaitu Undang-Undang Dasar Negara Republik Indonesia Tahun 1945. Disamping itu, hukum yang diterapkan dan ditegakkan harus mencerminkan kehendak rakyat, sehingga harus menjamin adanya peran serta warga negara dalam proses pengambilan keputusan kenegaraan. Hukum tidak dibuat untuk menjamin kepentingan kepentingan beberapa orang yang berkuasa, melainkan untuk menjamin kepentingan segenap warga negara (Gaffar, 2012).

Hans Kelsen memberikan argumentasi bahwa dalam kaitan negara hukum yang juga merupakan negara demokratis setidak-tidaknya harus memiliki 4 (empat) syarat rechtsstaat. Pertama, negara yang kehidupannya sejalan dengan konstitusi dan Undang-Undang; kedua, negara yang mengatur mekanisme pertanggung jawaban atas setiap kebijakan dan tindakan yang dilakukan oleh penguasa; ketiga, negara yang menjamin kemerdekaan kekuasaan kehakiman serta adanya peradilan administrasi negara; dan keempat, negara yang memilindungi hak asasi manusia (Simamora, 2014).

Dari argumen yang diberikan oleh Hans Kelsen tersebut dapat di simpulkan bahwa konsep hak asasi manusia tidak dapat dipisahkan dengan keberadaan Negara hukum yang tentunya mengedepankan dan melindungi hak asasi manusia. Oleh karena itu berbicara Negara hukum tentunya tidaklah mungkin terlewatkan pembahasan tentang HAM.

JOURNAL OF HUMANITIES, SOCIAL SCIENCES AND BUSINESS | JHSSB

https://ojs.transpublika.com/index.php/JHSSB/ 


\subsection{Konsepsi Negara Demokrasi Pancasila Dalam Kaitannyadengan HAM}

Kata "Demokrasi" berasal dari dua kata, yaitu "Demos" yang berarti rakyat dan "Cratos/Cratein" yang berarti pemerintahan, sehingga dapat diartikan sebagai pemerintahan yang berasal rakyat, atau yang lebih kita kenal sebagai pemerintahan dari rakyat, oleh rakyat dan untuk rakyat (Jailani, 2015). Secara etimologis dalam bahasa yunani kuno demokrasi dapat diartikan sebagai kekuatan atau aturan rakyat (Sander et al., 2010).

Negara demokrasi yang menganut bentuk atau mekanisme sistem pemerintahan dengan mewujudkan kedaulatan rakyat atas negara untuk dijalankan oleh pemerintah negara tersebut. Sehingga, isu mengenai demokrasi akan selalu berhubungan dengan isu mengenai hak asasi manusia. Perjuangan menegakkan demokrasi merupakan salah satu upaya umat manusia dalam rangka menjamin dan melindungi hak asisnya (Rosana, 2016).

Bagi bangsa Indonesia sendiri, demokrasi telah menjadi pilihan sejak para pendiri bangsa mempersiapkan dasar-dasar Indonesia merdeka. Demikian pula halnya dengan perlindungan dan penghormatan HAM yang telah diakui dalam Undang- Undang Dasar Republik Indonesia Tahun 1945 sebelum perubahan. Namun, tak selamanya negara yang demokrasi menjamin tegaknya HAM.

Lebih lanjut, Janedjri M. Gaffar (2012) menyebutkan Demokrasi dan HAM bagaikan dua sisi mata uang yang tidak bisa dipisahkan. Perlindungan HAM adalah tujuan sekaligus prasyarat bagi berjalannya demokrasi. Sebaliknya, kegagalan perlindungan dan penghormatan HAM akan menjadi ancaman bagi demokrasi. Pernyataan dari Janedjri M. Gaffar dapat dibenarkan dengan melihat fakta pelaksanaan demokrasi dan HAM pada masa orde baru.

Praktik kehidupan demokratis, sebagaimana banyak terjadi di negara-negara berkembang, termasuk Indonesia sering terkecoh pada format politik yang kelihatannya demokratis, tetapi dalam praktiknya otoriter sebagaimana terjadi pada masa orde baru.

Akibat inkonsistensi dalam sikap dan pemikiran dalam menegakkan nilai-nilai dasar demokrasi, pada akhirnya orde baru terseret dalam praktik-praktik pemerintahan pragmatis dan otoriter dan hukum ditundukkan untuk mengabdi kepada sistem kekuasaan represif (Huda, 2012).

Mengingat masih banyaknya bentuk pelanggaran HAM di Indonesia perlu dilihat bagaimana kedudukan HAM dalam sistem hukum Indonesia. Kedudukan tersebut akan dilihat berdasarkan teori sistem hukum yang dikemukakan oleh Lawrence M. Friedman:

1) Substansi Hukum

Substansi tersusun dari peraturan-peraturan dan ketentuan mengenai bagaimana institusi-institusi itu harus berperilaku.

H.L.A Hart berpendapat bahwa ciri khas suatu sistem hukum adalah kumpulan ganda dari peraturanperaturan. Suau sistem hukum adalah kesatuan dari "peraturan-peraturan primer" dan "peraturan-peraturan sekunder". Baik peraturan primer maupaun peraturan sekunder adalah sama- sama output dari sebuah sistem hukum (Friedman, 2011).

Sudah menjadi ketentuan ketatanegaraan sebagai suatu kesepakatan serta doktrin kenegaraan, bahwa pancasila adalah pandangan hidup, ideologi bangsa Indonesia serta "sumber segala sumber hukum" Indonesia. Dalam konteks pancasila sebagai segala sumber hukum, kita uji dengan teori pakar hukum kenegaraan Hans Kelsen yang lazim 


\section{JOURNAL OF HUMANITIES, SOCIAL SCIENCES AND BUSINESS (JHSSB) \\ VOLUME 1 ISSUE 2 (2022)}

dianalogikan dengan Teori Tangga atau Stuffen Theory. Berdasararkan teori Stuffen Theory maka kedudukan pancasila berada pada tangga tertinggi. Hal ini berarti bahwa Pancasila harus diletakkan sebagai kaidah dasar, groundnorms atau sumber segala sumber hukum yang menjadi dasar bagi berlakunya Undang-Undang Dasar Republik Indonesia Tahun 1945 (Bisri, 2014).

Pancasila sebagai groundnorms telah mengandung pengakuan HAM, hal ini dapat dilihat dari. Pertama, sila ketuhanan secara tersirat memberikan kewajiban bagi negara untuk menjamin kemerdekaan tiap-tiap penduduk untuk memeluk agamnya masing-masing dan beribadat menurut agama dan kepercayaannya itu. Kedua, Kemanusian yang adil dan beradab, sila kedua ini kemudian diejahwantahkan dalam Pasal-Pasal Undang-Undang Dasar Republik Indonesia Tahun 1945 yang selaras dengan prinsip HAM. Nilai nilai yang terkandung didalam pengejahwantahan tersebut diantaranya; (a) pemeliharaan, pengayoman terhadap jiwa atau diri ini mulai dari yang lahir sampai yang bathin; (b) perlindungan terhadapkeberlangsungan kehidupan individu, perlindungan diri pribadi, keluarga, kehormatan dan martabatnya, Ketiga, Keadilan sosial bagi seluruh rakyat Indonesia, secara umum keadilan sosial bagi seluruh rakyat Indonesia berarti bahwa setiap orang Indonesia mendapat perlakuan yang adil dalam bidang hukum, politik, sosial, ekonomi dan kebudayaan (Pimpinan MPR dan Tim Kerja Sosialisasi MPR Periode 20092014, 2014).

Disamping pancasila, Undang-Undang Dasar Republik Indonesia Tahun 1945 juga telah memuat aturan mengenai HAM baik sebelum amandemen maupaun pasca amandemen. Perbedaanya, pengaturan HAM dalam Undang-Undang Dasar pasca amandemen lebih luas pengaturannya, yang awalnya hanya 5 Pasal (hak katas pekerjaan dan penghidupan yang layak bagi kemanusiaan, kemerdekaan berserikat dan berkumpul serta mengeluarkan pikiran dengan lisan maupaun tulisan, jaminan kemerdekaan beragama dan berkepercayaan, serta ha katas pengajaran, ha katas akses sumber daya alam) menjadi setidaknya 17 Pasal (dengan 38 substansi hak-hak yang beragam) yang terkait dengan HAM (Wiratraman, 2007). Menurut Lindsey hasil amandemen Undang-Undang Dasar Republik Indonesia Tahun 1945 dibidang HAM paling impresif karena mencakup daftar HAM yang luas, melebihi konstitusi negara-negara maju, serta mandemen tersebut lebih mampu menghadirkan asas konstitusionalisme dibandingkan sebelumnya (Kurnia, 2014).

Universal Declaration of Human Right (UDHR) atau Deklarasi Universal Hak Asasi Manusia (DUHAM) yang lahir pada 10 Desember 1945 di Paris merupakan respon dari mayoritas masyarakat dunia bahwa manusia dilahirkan dengan kebebasan dan memiliki kesamaan derajat serta dihadapan hukum.

Pengaturan mengenai HAM yang ada, baik dalam Pancasila maupun Undang-Undang Dasar Republik Indonesia Tahun 1945 kemudian di formalkan kedalam Undang-Undang yaitu Undang-Undang Nomor 39 Tahun 1999 Tentang Hak Asasi Manusia dan UndangUndang Nomor 26 Tahun 2000 Tentang Pengadilan Hak Asasi Manusia dan peraturan perundangundangan lainnya yang mengatur mengenai HAM seperti ratifikasi Konvensi Hak-Hak Sipil dan Politik melalui UndangUndang No. 12 Tahun 2005, ratifikasi konvensi tentang hakhak politik perempuan melalui Undang-Undang No. 68 Tahun 1958, ratifikasi International Convention On The Elimination of All Forms of Racial Discrimination 1965 melalui UndangUndang No. 29 Tahun 1999, ratifikiasi kovenan internasional tentang Hak- 
Hak EKOSOB melaui Undang- Undang No. 11 Tahun 2005.

2) Struktur Hukum

Struktur hukum adalah komponen struktural atau organ yang bergerak di dalam suatu mekanisme, baik dalam membuat peraturan, maupun dalam menerapkan atau melaksanakan peraturan (Purba, 2017).

Salah satu perubahan yang dilakukan pasca amandemen Undang-Undang Dasar Republik Indonesia Tahun 1945 ialah semakin besarnya perhatian masyararakat dan pemegang kekuasaan untuk menegaskan dan meneggakkan HAM. Implikasi dari amandemen Undang-Undang Dasar Republik Indonesia Tahun 1945 juga telah melahirkan lembaga-lembaga yang bersifat Ad Hoc yang dibentuk dengan Undang- Undang dan lembaga-lembaga peradilan yang berperan signifikan dalam penegakan HAM di Indonesia. Setidaknya telah ada dua lembaga yang berperan dalam penegakan HAM di Indonesia, yaitu: Pertama, lembaga negara penegak HAM yang terdiri dari Komnas HAM, Komisi Perlindungan Anak Indonesia (KPAI), Komnas Perempuan, Komisi Kebenaran dan Rekonsiliasi. Kedua, lembaga peradilan sebagai penegak HAM yang terdiri dari Pengadilan HAM dan Mahkama Konstitusi (Putra, 2015).

3) Kultur Hukum

Kultur Hukum/Budaya hukum, dalam pengertian Friedman (1998), adalah "nilai, pendapat, sikap dan keyakinan tentang hukum" (Ginsburg, 2010). Sedangkan Menurut Esmi Warassih menyebutkan, bahwa:

"Kultur/ budaya hukum adalah nilai-nilai dan sikap-sikap yang merupakan pengikat sistem itu, serta menentukan tempat sistem itu ditengah-tengah budaya bangsa sebagai keseluruhan." (Warassih, 2016).

Pemahaman HAM sebagai tatanan nilai, norma, sikap yang hidup dalam masyarakat dan acuan bertindak pada dasarnya berlangsung sudah cukup lama baik sebelum kemerdekaan maupun setelah kemerdekaan.

Masyarakat Indonesia yang berkembang sejak masih sangat sederhana sampai modern, pada dasarnya merupakan masyarakat kekeluargaan. Masyarakat kekeluargaan telah mengenal pranata sosial yang menyangkut hak dan kewajiban warga masyarakat yang terdiri atas pranata religius yang mengakui bahwa manusia adalah ciptaan Tuhan Yang Maha Esa dengan segala hak dan kewajiban, pranata kekeluargaan sebagai wadah manusia hidup manusia hidup untuk mengembangkan keturunan dalam menjaga kelangsungan keberadaanya, pranata ekonomi yang merupakan upaya manusia untuk meningkatkan kesejahteraan, pranata pendidikan dan pengajaran untuk mengembangkan kecerdasan dan kepribadian informasi dan komunikasi untuk memperluas wawasan dan keterbukaan. Bangsa Indonesia menyadari dan mengakui bahwa setiap individu adalah bagian dari masyarakat dan sebaliknya masyarakat terdiri dari individu-individu yang mempunyai Hak Asasi serta hidup didalam lingkungan yang merupakan sumber daya bagi kehidupannya (Neta, 2011). Oleh karena itu, kesadaran akan pentingnya perlindungan dan penegakan HAM tidak hanya ditegakkan oleh pemerintah melalui lembaga yang dibentuk oleh pemerintah, melainkan melalui LSM dan/atau NGO yang bergerak dalam bidang HAM yang didirikan oleh masyarakat maupun kelompok orang sebagai bagian kesadaran akan pentingnya perlindungan dan penegakan hukum di Indonesia. LSM dan/atau NGO tersebut 


\section{JOURNAL OF HUMANITIES, SOCIAL SCIENCES AND BUSINESS (JHSSB) \\ VOLUME 1 ISSUE 2 (2022)}

diantaranya Yayasan Lembaga Bantuan Hukum Indoneisa (YLBHI), Lembaga Bantuan Hukum (LBH), Biro Konsultasi dan Bantuan Hukum (BKBH) Perguruan Tinggi dan Komisi Orang Hilang dan Korban Tindak Kekerasan (KONTRAS).

\section{KESIMPULAN}

Indonesia adalah negara hukum termuat dalam Pasal 1 ayat (3) Undang-Undang Dasar Republik Indonesia Tahun 1945. Meskipun dalam penjelasan Undang-Undang Dasar Republik Indonesia Tahun 1945 digunakan istilah rechtsstaat, namun yang dianut oleh negara Indonesia bukanlah konsep rechtsstaat maupun rule of law. Alasannya, Konsep negara hukum sebenarnya bukanlah konsep yang lahir dari kebudayaan Indonesia melainkan dari dunia barat. Sebagai negara yang berlandaskan pancasila konsep negara hukum Indonesia merupakan konsep negara hukum pancasila. Berbicara mengenai perlindungan HAM dalam konsep negara hukum, baik rechtsstaat, rule of law maupun negara hukum pancasila sama- sama mengakui adanya jaminan dan perlindungan terhadap HAM. Dalam konteks negara hukum pancasila HAM telah termuat di dalam pancasila itu sendiri. Dalam sila pertama misalnya. Ketuhanan Yang Maha Esa, dalam sila ini pada prinsipnya telah menegaskan adanya kebebasan bagi setiap warga negara untuk memeluk agamanya masingmasing dan beribadah sesuai dengan agama dan kepercayaannya, namun tetap dalam arti yang positif.

Perjuangan menegakkan demokrasi merupakan salah satu upaya umat manusia dalam rangka menjamin dan melindungi hak asasinya. Di Indonesia, sebagai sebagai negara demokrasi pancasila, perlindungan HAM menjadi tujuan sekaligus prasyarat bagi berjalannya demokrasi. Dimana prinsip persamaan bagi seluruh rakyat Indonesia, keseimbangan hak dan kewajiban, kebebasan yang bertanggung jawab dan memujudkan keadailan bagi seluruh rakyat merupakan bentuk pengakuan dan penghormatan terhadap HAM dalam konsep negara demokrasi pancasila.

\section{DAFTAR PUSTAKA}

Al-Khawarizmi, D. A. (2011). Hukum Administrasi Negara. Negara Hukum. https://www.negarahukum.com/hukum-administrasi-negara.html

Assiddiqie, J. (2012). Hukum Tata Negara dan Pilar-Pilar Demokrasi, Ed.2, Cet.2,. Sinar Grafika.

Bisri, I. (2014). Sistem Hukum Indonesia Prinsip - Prinsip dan Implementasi Hukum di Indonesia (1st ed., Vol. 9). Rajawali Pers.

Friedman, L. M. (2011). Sistem Hukum: Perspektif Ilmu Sosial, diterjemahkan oleh M. Khozim. Cet. Ke-4. Bandung: Nusa Media, 110.

Gaffar, J. M. (2012). Demokrasi Konstitusional Praktik Ketatanegaraan Setelah Perubahan UUD 1945. Konstitusi Press.

Ginsburg, T. (2010). Lawrence M. Friedman's Comparative Law, with Notes on Japan. $J$. Comp. L., 5, 92.

Huda, N. (2012). Hukum Tata Negara Indonesia Edisi Revisi. Jakarta: Rajawali Pers.

Jailani, J. (2015). Sistem Demokrasi di Indonesia Ditinjau Dari Sudut Hukum Ketatanegaraan. INOVATIF| Jurnal Ilmu Hukum, 8(1).

Kurnia, T. S. (2014). Interpretasi Hak-Hak Asasi Manusia oleh Mahkamah Konstitusi Republik Indonesia Melalui Pengujian Undang-Undang. 
Marbun, R. (2014). Grand Design Politik Hukum Pidana dan Sistem Hukum Pidana Indonesia Berdasarkan Pancasila dan Undang-Undang Dasar Negara Republik Indonesia 1945. Padjadjaran Journal of Law, 1(3).

Neta, Y. (2011). demokrasi dan hak asasi manusia dalam konsep negara hukum (Quo vadis demokrasi dan ham di indonesia di era globalisasi).

Purba, I. P. (2017). Penguatan budaya hukum masyarakat untuk menghasilkan kewarganegaraan transformatif. Jurnal Civics: Media Kajian Kewarganegaraan, $14(2), 146-153$.

Putra, M. A. (2015). Eksistensi lembaga negara dalam penegakan Hak Asasi Manusia di Indonesia. Fiat Justisia: Jurnal Ilmu Hukum, 9(3).

Ridlwan, Z. (2011). Negara Hukum Indonesia Kebalikan Nachtwachterstaat. Fiat Justisia: Jurnal Ilmu Hukum, 5(2).

Rosana, E. (2016). Negara demokrasi dan hak asasi manusia. Jurnal Tapis: Jurnal Teropong Aspirasi Politik Islam, 12(1), 37-53.

Sander, F., Fukuyama, T., Putnam, R., O’Donnell, P. C. S. G., Andreas, L. D. M. F. P., Levitsky, S. S., Way, L., Gilley, L. W. B., Shevtsova, I. K. L., Mungiu-Pippidi, J. R. A., \& Nodia, V. T. G. (2010). Democracy's Past and Future. Journal of Democracy, 2l(1).

Simamora, J. (2014). Tafsir Makna Negara Hukum dalam Perspektif Undang-Undang Dasar Negara Republik Indonesia Tahun 1945. Jurnal Dinamika Hukum, 14(3), 547-561.

Warassih, E. (2016). Pranata Hukum Sebuah Telaah Sosiologis (Vol. 4). Pustaka Magister. Wiratraman, H. P. (2007). Hak-Hak konstitusional warga Negara setelah amandemen UUD 1945: konsep, pengaturan dan dinamika implementasi. Jurnal Hukum Panta Rei, 1(1), $1-18$.

Yuliartha, I. G. (2009). Lembaga Praperadilan Dalam Perspektif Kini Dan Masa Mendatang Dalam Hubungannya Dengan Hak Asasi Manusia. 